\title{
Investigation and Study on the "Dragon Boat Race" of Ankang Folk Sports
}

\author{
Fenshan Liu',a, Shilong Wei ${ }^{2}$ \\ ${ }^{1,2}$ College of Physical Education, Yulin University 719000
}

\begin{abstract}
This paper investigates and studies the "dragon boat race" of folk sports activities in Ankang city to understand the cultural connotation of dragon boat race and the development history of "dragon boat race" in this region. In this paper, the literature review, questionnaire survey, field visits, and statistics and analysis of data are used to investigate and study the current situation of the development of the "dragon boat race" in Ankang. It aims to provide a valuable and meaningful reference for the inheritance and development of the "dragon boat race" movement in Ankang.
\end{abstract}

\section{Introduction}

Dragon boat race is one of the important traditional folk activities in China. The dragon boat race is a water sports event that integrates entertainment and competition. It has the characteristics of integrating popularity and strengthening physical fitness. Due to the differences of folk customs and geographical conditions in different parts of China, dragon boat races in different regions are also diversified.

Since the development of dragon boat race, China has gradually begun to attach importance to traditional folk sports. In 2007, the dragon boat race of the Dragon Boat Festival was included in the protection list of the intangible cultural heritage of Shaanxi Province, and the dragon boat race was protected and passed down. Under the current rapid development of social conditions, the geographical environment, material conditions and the groups participating in the dragon boat race of the Ankang dragon boat race have changed to some extent. Although on the surface, the dragon boat race has passed and completed the modern transformation of the folklore movement, and developed into a domestic official competition project, with a complete competition system and even going abroad, and there is no gradual disappearance or even demise like other folk sports activities, in fact there are still many problems. Then, can the dragon boat race in Ankang adapt to the modern society which combines culture and sports, and how will the dragon boat race go together in the face of this heavy test?

This paper investigates the development status of the dragon boat race in Ankang city. The investigation finds that the operation mode of the Ankang dragon boat race is initiated by the government, assisted by dragon boat associations and clubs in various regions, and intervened

\footnotetext{
a Corresponding author: author@e-mail.org
}

by the companies in the joint undertaking. In the game, people can understand the purpose and significance of holding folk sports activities, so as to better inherit folk sports. As a student in Ankang district, I have been fond of the dragon boat race of Ankang since I was a child. I was shocked by its grand spectacle and was infected by the solidarity of the contestants. Therefore, I would like to put forward some suggestions for the "dragon boat race" folk sports activities of Ankang, and make my due contribution to the protection and inheritance of the folk sports activities of Ankang.

\section{Research objects and methods}

\subsection{Research objects}

The 30 teams of "dragon boat race" in Ankang City are the research objects.

\subsection{Research methods}

This paper uses literature, questionnaire, field visits and mathematical statistics to conduct research and analysis.

\section{Results and analysis}

\subsection{The current situation of "dragon boat race" in folk sports in Ankang}

3.1.1 Sponsor of the "dragon boat race" of folk sports in Ankang in recent three years 
Table 1 Sponsor types of the "dragon boat race" of folk sports in Ankang in recent three years

\begin{tabular}{|c|c|}
\hline Year & Enterprise Name \\
\hline 2015 & Finance, Real estate, Sports, Food \\
\hline 2016 & $\begin{array}{c}\text { Communications, Finance, Advertising, Real } \\
\text { estate, Sports, Food }\end{array}$ \\
\hline 2017 & $\begin{array}{l}\text { Real estate, Communications, Finance, } \\
\text { Advertising, Automobiles, Sports, Food }\end{array}$ \\
\hline
\end{tabular}

The survey shows that the sponsors of dragon boat race involve communication, real estate, advertising, automobile, food, sports, finance and other aspects. The enterprise industry is widely distributed and is not limited to a certain field. This has a lot to do with the sponsorship motivation of the enterprise. Enterprises like automobiles and real estate are mostly designed to increase the influence of their brands and make them widely known, increase their market share and increase market sales. It shows that the dragon boat race has a certain influence on various industries, and it can promote the development of all walks of life to a certain extent.

\subsubsection{Occupation and age distribution of athletes in the dragon boat race of folk sports in Ankang}

According to the information provided by the Dragon Boat Association of Ankang, the contestants of the dragon boat race in Ankang are divided into three main categories: One is the farmers who have a certain basis for rowing dragon boats and a period of training with the competitive capacity. The 2 nd kind is the enterprise personnel that likes dragon boat race.

Table 2 Contestants in the "dragon boat race" of Ankang folk sports $(n=80)$

\begin{tabular}{ccccc}
\hline $\begin{array}{c}\text { Contestants' } \\
\text { occupation }\end{array}$ & Farmers & Students & $\begin{array}{c}\text { Enterprise } \\
\text { units }\end{array}$ & Others \\
\hline $\begin{array}{c}\text { Number of } \\
\text { people (n) }\end{array}$ & 39 & 9 & 26 & 6 \\
$\begin{array}{c}\text { Percentage } \\
(\%)\end{array}$ & 48.8 & 11.2 & 32.5 & 7.5 \\
\hline
\end{tabular}

As can be seen from Table 2, farmers as the main force and cultural inheritor of the dragon boat race have always been the absolute subject of the dragon boat race. According to the Ankang Dragon Boat Association, there are more than 30 teams participating in the dragon boat training and competition in Ankang City. Most of these teams are sports teams formed by dragon boat enthusiasts of farmers and enterprise units. Therefore, at present, the city's dragon boat sports lack professional athletes, and the competition team is therefore unstable. It may be organized temporarily to participate in the race during the competition. After the game, they are busy with the work and neglect the usual training. This is also the main reason for the slow improvement of the overall level of the dragon boat sports.
Table 3 The age of contestants in the "dragon boat race" of Ankang folk sports

\begin{tabular}{ccccc}
\hline Age & $\begin{array}{c}\text { Under the } \\
\text { age of } 20\end{array}$ & $20-40$ & $41-60$ & $\begin{array}{c}\text { Above the } \\
\text { age of } 60\end{array}$ \\
\hline $\begin{array}{c}\text { Number of } \\
\text { people (n) }\end{array}$ & 9 & 23 & 37 & 11 \\
Percentage (\%) & 11.3 & 28.7 & 46.3 & 13.7 \\
\hline
\end{tabular}

As can be seen from Table 3, the age distribution of the dragon boat athletes is between 41 and 60 years old, accounting for $46.3 \%$ of the total number. This part of the age retains a passion for the traditional sports. However, few young people have great interest in dragon boats. They lack the basis of dragon boating and will not actively participate in dragon boat training. This makes the reserve of dragon boat races scarce and lacks a new generation of athletes to supplement them. The age structure of the team members is further aging.

\subsubsection{Coaches and training of dragon boat team in dragon boat race in Ankang}

Table 4 The situation table of the coaches of the dragon boat team in Ankang $(\mathrm{n}=23)$

\begin{tabular}{cccc}
\hline $\begin{array}{c}\text { Situation } \\
\text { of coach }\end{array}$ & Professional & $\begin{array}{c}\text { Non- } \\
\text { professional }\end{array}$ & $\begin{array}{c}\text { With long-term } \\
\text { experience in } \\
\text { dragon boat }\end{array}$ \\
\hline $\begin{array}{c}\text { Number of } \\
\text { people (n) }\end{array}$ & 1 & 5 & 17 \\
$\begin{array}{c}\text { Percentage } \\
(\%)\end{array}$ & 4.3 & 21.7 & 74 \\
\hline
\end{tabular}

It can be seen from Table 4 that most of the dragon boat teams in Ankang City are trained by coaches with longterm dragon boat experience, accounting for $74 \%$ of the number of people surveyed, indicating that the dragon boat team in Ankang City lacks professional guidance coaches.

Table 5 Training table of dragon boat team in all parts of Ankang $(\mathrm{n}=23)$

\begin{tabular}{cccc}
\hline $\begin{array}{c}\text { Training } \\
\text { situation }\end{array}$ & $\begin{array}{c}\text { Professional } \\
\text { training }\end{array}$ & $\begin{array}{c}\text { Non } \\
\text { professional } \\
\text { training }\end{array}$ & $\begin{array}{c}\text { Temporary } \\
\text { training before } \\
\text { the game }\end{array}$ \\
\hline $\begin{array}{c}\text { Number of } \\
\text { teams }(\mathrm{n})\end{array}$ & 1 & 3 & 19 \\
$\begin{array}{c}\text { Percentage } \\
(\%)\end{array}$ & 4.3 & 13.1 & 82.6 \\
\hline
\end{tabular}

According to Table 5, only one team can carry out professional training, accounting for $4.3 \%$ of the surveyed team. Most of the remaining teams are temporarily organized training before each match, accounting for $82.9 \%$ of the surveyed teams, indicating that the professional training of the Ankang dragon boat sports is very scarce.

\subsubsection{The development of women's dragon boat race in Ankang}

Through field visits to the staff of various dragon boat teams in Ankang, it is known that the current situation of 
women' s dragon boat race in Ankang is not optimistic. There are only professional dragon boat teams in colleges and universities, and there are few or no dragon boat teams in different regions. Therefore, the development of women' s dragon boat race in Ankang lags behind that in other regions.

\subsubsection{People's attitude towards dragon boat race in Ankang}

Table 6 People's attitude towards dragon boat race in Ankang $(n=123)$

\begin{tabular}{ccccc}
\hline Attitude & $\begin{array}{c}\text { Like it } \\
\text { very } \\
\text { much }\end{array}$ & $\begin{array}{c}\text { Quite } \\
\text { like it }\end{array}$ & $\begin{array}{c}\text { Generally } \\
\text { like }\end{array}$ & $\begin{array}{c}\text { Not } \\
\text { interested }\end{array}$ \\
\hline $\begin{array}{c}\text { Number of } \\
\text { people }\end{array}$ & 67 & 32 & 18 & 6 \\
$\begin{array}{c}\text { Percentage } \\
(\%)\end{array}$ & 54.5 & 26 & 14.6 & 4.9 \\
\hline
\end{tabular}

As can be seen from Table 6, the people of Ankang generally like to hold dragon boat races, accounting for more than $80 \%$ of the total number of people surveyed. Only $4.9 \%$ of the people are not interested in dragon boat race, which shows that dragon boat race is very popular with people in Ankang.

\subsection{The problems of "dragon boat race" in folk sports of Ankang}

In view of the overall development of Ankang dragon boat race, the following questions are raised:

1. The source of funds for the dragon boat team has been simplistic and has not received universal attention from the society.

2. The reserve talents of dragon boat race are scarce, and a new generation of athletes are lacking. The age structure of the team members is further aging.

3. Although the dragon boat race has a long-term foundation in Ankang, the local dragon boat team lacks professional coaches and dragon boat racers, and the teams are not stable.

4. Compared with other regions, the development of the women' s competition in the Ankang dragon boat race is relatively lagging. In some places, there is no women' s competition at all.

5. There are many people who like dragon boat racing, but they do not pa y much attention to the special training of dragon boat racing.

\section{Conclusions and suggestions}

\subsection{Conclusions}

1. The dragon boat race has a certain influence on various industries, and it can promote the development of all walks of life to a certain extent.
2. The reserve talents of dragon boat race are scarce, and a new generation of athletes are lacking. The age structure of the team members is further aging.

3. The dragon boat teams in various places are not professional, the professional training team is almost no, and the coaches with professional knowledgeable are scarce.

4. The dragon boat races around Ankang involve very few women' s competitions, or even no women' $s$ competitions.

5. The people of Ankang are very fond of holding dragon boat race, which is very beneficial to the development of dragon boat sport in Ankang.

\subsection{Suggestions}

1. The government of Ankang should pay more attention to the dragon boat movement, establish a special museum for the dragon boat culture, and protect the dragon boat culture so as to inherit the dragon boat culture better.

2. The government should increase publicity, expand the influence of the dragon boat race, and promote the development model of the dragon boat team's alliance with enterprises.

3. Professional dragon boat racing coaches should be introduced to build a professional dragon boat team to improve the professionalism of the dragon boat sport.

4. In the dragon boat races, women' s competitions should be added to develop women' s dragon boat racing.

5. The dragon boat race can be introduced into the school-based curriculum, the dragon boat sports courses are set up at Ankang University and other colleges and universities, and "dragon boat race coaches training class" is set up regularly to recruit students in the city.

6. Taking the traditional culture festival "Dragon Boat Festival" as a platform, it is feasible and effective to spread and popularize the national fitness campaign in rural areas.

\section{References}

1. Chen Li. Wenzhou Region Dragon Boat Festival Culture Research [D]. Beijing Sport University, 2011

2. Cheng Dapeng. Countermeasures of Zhengzhou City, Dragon Boat Racing Event for Sustainable development [D]. Zhengzhou University, 2016.

3. Deng Fuping. Study on the Space of Lingnan Dragon Boat Race [D]. South China University of Technology, 2014.

4. Huang Chenan. An Inquiry into Dongguan Dragon Boat Culture [D]. Central China Normal University, 2013.

5. Li Chao. Research on the Evolution of Dragon Boat Race Function [D]. Liaocheng University, 2015.

6. Liang Zhicong. Research on the Development of Dragon Boat Sports in Macao, China [D]. Beijing Sport University, 2013. 